CEP Discussion Paper No 705

October 2005

\title{
The De-Collectivisation of Pay Setting in Britain 1990-1998: Incidence, Determinants and Impact Andy Charlwood
}

The Leverhulme Trust

Registered Charity No: 288371

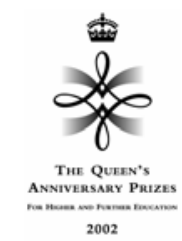




\begin{abstract}
Overall, collective bargaining coverage has dropped by around fourteen percentage points. This paper investigates the causes and consequences of the decline in collective bargaining in Britain between 1990 and 1998. One in three workplaces that practiced collective bargaining in 1990 had abandoned it by 1998 and the incidence and coverage of collective bargaining in newer workplaces was lower than in the workplaces they replaced. The abandonment of collective bargaining was not associated with an increase in individualised payment mechanisms or with the use of 'high involvement' HRM practices. Workplaces that abandoned bargaining reported less impressive productivity gains than other workplaces. Male wage inequality rose as a result of the decline of bargaining coverage and of weaker unions where collective bargaining remained. Higher levels of job creation in workplaces that abandoned collective bargaining balance these negative outcomes.
\end{abstract}

JEL Classification: J31, J5, M12

Keywords: Collective bargaining, de-collectivisation, wage dispersion

This paper is produced under the 'Future of Trade Unions in Modern Britain' Programme supported by the Leverhulme Trust. The Centre for Economic Performance acknowledges with thanks, the generosity of the Trust. For more information concerning this Programme please e-mail future_of_unions@lse.ac.uk

\title{
Acknowledgements
}

I would like to thank Richard Belfield, Jo Blanden, Alex Bryson, Chris Forde, John Forth, Kirstine Hansen, Steve Machin and participants in the 2003 Performance and Reward Conference at Manchester Metropolitan University, the British Academy of Management conference in Harrogate, a Labour, Employment and Performance seminar at Leeds University Business School and an Industrial Relations Research Unit seminar at the University of Warwick for helpful comments and advice. This paper is part of the CEP's Leverhulme Trust funded 'Future of Trade Unions in Modern Britain' programme, the financial assistance of the Leverhulme Trust is gratefully acknowledged. The Workplace Employee Relations Survey was originated by the Department of Trade and Industry, the Economic and Social Research Council, the Policy Studies Institute and the Advisory and Conciliation Service and distributed by the ESRC Data Archive at the University of Essex. The British Household Panel Survey was originated by the Institute of Social and Economic Research with funding from the Economic and Social Research Council and distributed by the ESRC Data Archive, both at the University of Essex. The usual disclaimers apply.

Andy Charlwood is a lecturer in Industrial Relations and Human Resource Management at Leeds

University Business School. Email: ac@lubs.leeds.ac.uk

Published by

Centre for Economic Performance

London School of Economics and Political Science

Houghton Street

London WC2A 2AE

All rights reserved. No part of this publication may be reproduced, stored in a retrieval system or transmitted in any form or by any means without the prior permission in writing of the publisher nor be issued to the public or circulated in any form other than that in which it is published.

Requests for permission to reproduce any article or part of the Working Paper should be sent to the editor at the above address.

(C) Andy Charlwood, submitted 2005

ISBN 0753019027 


\section{Introduction}

In Britain today, around 34 percent of the workforce have their pay and conditions determined by collective bargaining. This figure has changed only a little since 1998 (Kersley et al. 2005). Bargaining coverage has declined dramatically from a high point of 85 per cent in the mid to late 1970s. It is now lower than at any time since 1940 (Milner, 1995: 82). Given the key role of collective bargaining in the regulation of the employment relationship, this is not a trivial change. While the broad causes of British union decline are well known (cf. Brown \& Wadhwani 1990, Brown et al. 1997, Dunn \& Metcalf 1996, Kelly 1990, Metcalf 2001 and Pencavel 2003), relatively little is known about the specific causes and consequences of the decline in collective bargaining coverage in the 1990s. What we do know is largely confined to pages 196 - 199 of the 1998 Workplace Employee Relations Survey sourcebook (Millward et al. 2000), and case studies of Brown et al. (1998).

With this in mind, the aims of this paper are four-fold. First it attempts to measure more accurately the precise nature of the decline in aggregate collective bargaining coverage for the period $1990-1998$. Second, it asks what are the factors likely to have caused de-collectivisation? Third, it investigates the pay-setting and workplace governance arrangements that are replacing collective bargaining. Is decollectivisation is leading to 'substantive individualisation' or 'procedural individualisation' of pay setting arrangements (Brown et al. 1998)?

Do workplaces that abandon or fail to adopt collective bargaining have different systems of workplace governance, for example by making more extensive use of High Involvement Management systems, compared to workplaces that have collective bargaining? Fourth, it investigates the impact of abandoning collective bargaining on outcomes. Specifically, managerial perceptions of establishment performance and wage inequality.

Data to accomplish these tasks comes from the 1990 Workplace Industrial Relations Survey (WIRS90), the 1998 Workplace Employee Relations Survey (WERS98), its associated panel survey and the British Household Panel Survey (BHPS). The WIRS/WERS series offers the largest and most representative set of establishment level survey data available on the determination of pay in the context of wider employment relations structures and policies (Millward et al. 2000: 3 -9). The 
BHPS is a longitudinal panel data set consisting of 5,500 households and around 10,000 individuals and includes information on pay, employment and collective bargaining coverage (see Taylor et al. 2001 for more information on the survey, its methodology and representativeness).

\section{Accounting for the decline of collective bargaining coverage in}

\section{Britain}

Millward et al. (2000: 197) show that aggregate collective bargaining coverage in Britain (in workplaces with 25 or more employees) fell by 30 percentage points between 1984 and 1998, from 70 per cent coverage to 40 per cent coverage. 16 percentage points of this drop took place in the period $1984-1990$, the remaining 14 percentage points in the $1990-1998$ period. Decline in collective bargaining coverage in the 1980s was the result of newly established workplaces choosing not to bargain with unions. Union de-recognition in continuing workplaces during this period was not common (Beaumont and Harris 1995, Claydon 1989, Disney et al. 1995, Smith and Morton 1993). Using a simple shift-share analysis, Millward et al. estimated that around half of the decline in the 1990 - 1998 period was due to the decline of collective bargaining coverage in workplaces with union recognition. The other half was due the shrinking employment share of the unionised part of the economy. Brown et al. (2002: 201 - 3) build on this analysis. They argue that declining union coverage was the result of lower levels of union recognition in new establishments, falling coverage in continuing workplaces and individualisation of pay-setting arrangements in workplaces that continued to recognise unions, but abandoned pay bargaining. Compositional change may also have played a role. The first task of this paper is to try to quantify the relative importance of these different processes.

Table one shows that between 1990 and 1998 the proportion of workplaces with collective bargaining fell dramatically, while mean coverage in workplaces that 
had collective bargaining actually rose (suggesting that workplace with relatively low levels of collective bargaining coverage in 1990 were more likely to have abandoned it by 1998). It also shows that the incidence of workplace collective bargaining fell in continuing (panel) workplaces. Further analysis of the panel shows that a far greater number of continuing workplaces abandoned collective bargaining than adopted it. Overall, $16 \%$ of continuing workplaces abandoned collective bargaining over pay while just $1.3 \%$ of workplaces adopted it. Of workplaces those continuing workplaces that had collective bargaining in 199030 per cent had de-collectivised pay-setting by $1998^{1}$.

It is interesting to note that only two per cent of workplaces that abandoned collective bargaining also formally de-recognised trade unions ${ }^{2}$. In the overwhelming majority of workplaces that de-collectivised, collective agreements for determining pay remained in place even if they did not remain in operation. Of those panel workplaces where collective bargaining was operating in both 1990 and 1998, bargaining coverage fell in 21 per cent of workplaces (the mean fall in coverage was 19 percentage points). Coverage rose in 22 per cent of these workplaces (the mean rise was 31 percentage points). None of these figures varied significantly between the public and private sectors.

There were also dramatic differences between workplaces that left the WERS sample (because they closed or fell below 25 employees, from now on described as leavers) and workplaces that opened or grew from below 25 employees (joiners: leavers and joiners were identified using the methodology set out in Forth 2000). Around 63 per cent of leavers had collective bargaining compared to just 39 per cent of joiners. These trends were apparent in both public and private sector workplaces.

Multivariate shift share analysis was used to estimate the relative importance of change in continuing workplaces compared to differences between leavers and joiners in explaining overall decline in bargaining coverage. First, regression models of the determinants of union coverage for 1990 and 1998 were estimated using the WIRS90 and WERS98 cross-sections:

$$
C B_{i t}=\beta\left(\operatorname{comp}_{i t} \mid \operatorname{Con}_{i t}=1\right)+\beta\left(\operatorname{Comp}_{i t} \mid \operatorname{Con}_{i t}=0\right)+\varepsilon_{i t}
$$


Where $C B$ is collective bargaining coverage in workplace $i$ at time $t$. Con is a 0/1 dummy with the value of unity if workplace $i$ was operating in both 1990 and 1998. Therefore the notation shows that separate coefficients were estimated on the parameters of the continuing and non-continuing samples. Comp indicates the composition of the workforce and related factors like workplace size in workplace $i$ at time $t$. $E$ is an error term. The data were weighted to allow for the impact of the complex survey design on each workplace's probability of selection (Purdon and Pickering 2001) and, because the dependent variable of interest is aggregate collective bargaining coverage (as opposed to mean workplace collective bargaining coverage), each workplace's overall employment share ${ }^{3}$. Preliminary analyses revealed significant differences between the public and private sectors, so results are reported for the whole sample, private sector workplaces only and public sector workplaces only. The results were then used in the multivariate shift share analysis:

$\Delta C B=\left(\mathrm{X}^{98}-\mathrm{X}^{90}\right) \beta^{90}+\left(\beta^{98}-\beta^{90}\right) \mathrm{X}^{90}+\left(\mathrm{X}^{98}-\mathrm{X}^{90}\right)\left(\beta^{98}-\beta^{90}\right)$

Where $C B$ is collective bargaining coverage, $\beta$ is the vector of the coefficients from the regression model and $\mathrm{X}$ is the sample mean. Given the usual assumptions about zero means of error terms, these are not included in the shift-share analysis. The first term $\left(\left(X^{98}-X^{90}\right) \beta^{90}\right)$ is the effect of compositional change keeping propensity to unionize at 1990 levels. The second term $\left(\left(\beta^{98}-\beta^{90}\right) X^{90}\right)$ is the effect of changing propensity to unionize if composition is held at 1990 levels. Since in reality, neither propensity to unionize nor composition were held at 1990 levels, the results of the first two terms will not necessarily sum to the observed decline in union density. The third term $\left(\left(X^{98}-X^{90}\right)\left(\beta^{98}-\beta^{90}\right)\right)$ balances the equation so that the results are consistent with the observed drop in density in the samples (Green, 1992: 454). Table two presents the results of the shift-share analysis. Note that figures for total decline in aggregate coverage may vary somewhat from those reported in table 6.5 of Millward et al. (2000:197) and in table one because workplaces where it was not possible to establish if the workplace fell into the leaver/joiner or 
continuing workplaces categories and workplaces with missing observations for one or more of the independent variables were excluded from the analysis.

Overall, one quarter of the decline in collective bargaining coverage could be accounted for by compositional change with the remainder explained by behavioural change. Compositional change happened exclusively in continuing workplaces. Just over a quarter of the decline was a result of differences between leavers and joiners, with the remainder explained by change in continuing workplaces.

However, there were significant differences between the public and private sectors. Decline of bargaining coverage in the private sector was predominantly down to behavioural differences between leavers and joiners. In the public sector, Compositional change explained almost one third of the decline in bargaining coverage and differences between leavers and joiners did not contribute to declining bargaining coverage at all.

These findings put the case studies of Brown et al. (1998) in context; what Brown et al. call 'individualisation of pay-setting' was relatively common and significant in the public sector (although the incidence may be overstated if workplaces with pay review bodies in 1998 were wrongly classified as having collective bargaining in 1990, see note one), but less so in the private sector.

\section{The determinants of de-collectivisation in continuing workplaces}

Freeman and Kleiner (1990) suggest that management will be more likely to resist unions when the costs of unionisation are relatively high and the costs of resisting unions are relatively low. Brown et al.'s (1998) case studies identify two key stimuli for individualisation. First, exogenous shocks for example de-regulation or privatisation (which might lead to sudden increases in the cost of unionism). Second, as a response to difficult trading conditions which require labour costs to be reduced as a matter of urgency. However, they also found that management had a degree of strategic choice in deciding how to respond to these circumstances. Management could have pursued other options instead of de-collectivisation/individualisation, but chose not to (Brown et al. 1998: 14 - 25). Research into union de-recognition in the 1980s suggested that de-recognition was most likely to occur in workplaces where 
union density was relatively low (Claydon 1989). It seems likely that management might expect the costs of stopping bargaining with unions to be less in workplaces with low union density (because employee support for the union is lower). Some (but not all) of Brown et al.'s cases would seem to support this finding ${ }^{3}$.

The factors associated with ending collective bargaining were investigated via a probit analysis on those panel workplaces that had collective bargaining in $1990^{4}$. This form of regression analysis was used because the dependent variable (decollectivisation) is categorical. The results are reported in table three.

De-collectivisation was more likely among workplaces in the gas, electricity and water supply SIC group - an industry particularly prone to re-structuring as a result of de-regulation and privatisation. Workplaces where collective bargaining operated at the level of the workplace were particularly vulnerable to decollectivisation, perhaps because these small bargaining units were of less strategic importance to the national trade union (Willman 2001), with the consequence that the workplace union organisation had fewer resources to draw on in order to defend itself. Workplaces with 500 or more employees in 1990 were less likely to abandon pay bargaining. Transaction cost economics would suggest that the economies of scale from determining pay collectively would be greater in these large workplaces, so there would be less incentive for management to de-collectivise. However, workplaces that grew in size were more likely to have de-collectivised. This is in line with Addison and Heywood's (2004) finding that employment growth was stronger in non-union workplaces. As predicted, de-collectivisation was less likely in workplaces with higher levels of union density, and more likely in workplaces with low union density. It is also interesting to note that de-collectivisation was more likely in workplaces with a higher proportion of female employees; perhaps because employers felt that the risk of a backlash from employees was lower with a predominantly female workforce. 


\section{Pay determination and workplace governance in the absence of collective bargaining}

These issues were investigated using data from the WERS98 management questionnaire. The advantages of using the cross-section data here are that it is possible to compare results across continuing workplaces and joiners. The data also provide richer information about pay-setting arrangements, the pay of individual employees and related management practices than the panel dataset. The data were broken down into five categories. 1) Continuing workplaces with union recognition and collective bargaining (20 per cent of the weighted sample). 2) Joiners with union recognition and collective bargaining(11 per cent). 3) Continuing workplaces with union recognition but no collective bargaining (as only one per cent of workplaces fell into this category in 1990, I am confident that most workplaces in this category in 1998 had de-collectivised) and continuing workplaces without union recognition and collective bargaining where union de-recognition had taken place within the last five years. This group was used as a proxy for workplaces that had de-collectivised pay setting (12.5 per cent). 4) Continuing workplaces without union recognition or collective bargaining where de-recognition had not taken place in the previous five years (31.5 per cent). It is assumed that none of these workplaces practised collective bargaining in the 1990-1998 period. However, it is possible that some of these workplaces may have de-recognised unions between 1990 and 1993, although given the low level of union de-recognition in the 1990 - 1998 period, this is unlikely to be a major issue. 5) Joiners without union recognition or collective bargaining coverage (25 per cent).

Once again, weights were used in the analysis of both data sets in order to correct for the complex sample design. As highlighted above, the disadvantage of using the cross-section data in this way is that there is a risk that workplaces may be misclassified. Specifically, a small number of continuing workplaces may be treated as if they have never had collective bargaining when they are actually workplaces that de-collectivised pay setting. And a small number of workplaces that are classified as having de-collectivised pay setting between 1990 and 1998 may have not practised collective bargaining in 1990. There were also a larger number of workplaces that were excluded from the analysis because of non-response to the age of workplace 
question. However, managers who do not know the age of their workplace are likely to be randomly distributed, so this should not bias the results.

\subsection{Pay determination}

Collective bargaining could be replaced by a system of wage determination based upon either 'substantive individualisation' or 'procedural individualisation' Brown et al. 1998: i). Substantive individualisation occurs when there is differentiation of individual employees' contracts. Procedural individualisation removes collective pay determination mechanisms but maintains standardised employment contracts. Transaction cost considerations and normative notions of fairness among employees may lead employers who de-collectivise pay setting arrangements to favour procedural individualisation despite the benefits from substantive individualisation predicted by principal-agent theory (Brown et al. 1998: 5 -8). In the majority of organisations studied by Brown et al., collective bargaining was replaced by procedural individualisation rather than substantive individualisation.

WERS98 provides three measures that might indicate substantive individualisation. 1) Whether or not negotiations with individual employees had increased in importance over the last five years (asked in continuing workplaces only). 2) Whether or not there was a system of performance related pay linked to individual performance. 3) Whether or not non-standard contracts were used for employees in the largest occupational group. Table four reports the results of probit analyses on each of these measures. The results suggest that de-collectivisation and an absence of collective bargaining were not significantly associated with an increased probability of any of the measures of substantive individualisation. Indeed, continuing workplaces that abandoned collective bargaining were actually less likely to use performance related pay. Therefore, the demise of collective bargaining has not result in widespread substantive individualisation of pay determination. 


\subsection{Workplace governance}

Purcell and Ahlstrand (1994: 178) offer a typology of employment relations management styles that considers the dynamics of employment relations management systems. They argue that employers moving away from collective bargaining ('bargained constitutionalism') towards a system based on individualism can move towards a 'sophisticated human relations' system based on high commitment management, or towards a 'traditional' system without employee representation or voice based around cost minimisation. Brown et al.'s case studies found rather more evidence of the moves towards traditional cost minimisation systems than of moves towards sophisticated human relations systems.

To investigate these questions, it is first necessary to operationalise the employment relations systems proposed by Purcell and Ahlstrand (1994). This is not necessarily a straightforward task. There is considerable disagreement about the components of Human Resource Management (HRM) / High Involvement Management (HIM) etc. (Wood 1999). Here I use an empirically grounded measure developed by Wood et al. (2000) based on a latent class model which categorises workplaces as 'low involvement' 'medium involvement' or 'high involvement' (further details of the methodology involved here can be found in Wood et al. 2000) ${ }^{5}$. A low involvement approach would seem to fit with Purcell and Ahlstrand's cost minimisation category, while the high involvement approach fits with the sophisticated human relations category. A mixed or medium involvement approach would appear to suggest a halfway house between collective/constitutional and individualist management approaches. Table five presents results of ordered probit analyses that investigate the relationship between high involvement management and collective bargaining.

Results suggest little relationship between collective bargaining or it's absence and HIM. However, results for the private sector only suggest that workplaces which abandoned collective bargaining are significantly less likely to have adopted a High Involvement Management approach, and are significantly more likely to follow a low involvement management approach. Overall, these results suggest that collective 
bargaining is not being replaced by individualised 'high involvement management' and in the private sector at least, the abandonment of bargaining is associated with an increased probability of a 'bleak house' cost minimisation strategy.

\section{Outcomes: establishment performance and wage inequality}

\section{1 Establishment performance}

On the one hand, it might be expected that the opportunity to reduce labour costs that de-collectivisation presents (Brown et al. 1998: 52 - 55) would lead to improved establishment performance. On the other hand, the fact that establishments that decollectivise often do so in response to crisis may indicate that these establishments are comparatively poor performers, so even after substantial improvements, performance may not rise above average. Furthermore, Brown et al.'s matched case studies found that de-collectivisation was by no means the only management strategy for dealing with crisis. Strategies of labour management co-operation seemed to be at least as successful as de-collectivisation strategies in these circumstances (Brown et al. 1998: 53). If de-collectivisation invariably led to superior establishment performance, we would expect de-collectivisation to have been adopted more widely in continuing workplaces.

Theory also points in two directions. First, collective bargaining may lower productivity by allowing workers to capture rents due to capital so reducing investment (Metcalf, 1989). Alternatively, collective bargaining may act as a force for economic dynamism because it raises the incentive for management to modernise (Nolan and Marginson 1990: 239). Removing collective bargaining may therefore remove an incentive to raise productivity.

Research that claims to demonstrate a link between particular management practices and establishment performance based on the analysis of cross-section survey data has received heavy criticism from a number of directions (e.g. McCarthy, 1994, Addison and Belfield, 2001). With these criticisms in mind, I proceed with caution. The following results do not claim to establish a causal relationship between the presence of collective bargaining and establishment performance; the arrow of 
causality may run the other way. Any identified relationships may be the result of omitted variable bias. There must also be a question mark over the precise meaning of self-reported assessments of establishment performance provided by managers. What the results do show is whether or not there is a statistically significant association between collective bargaining, its abandonment or absence and managerial perceptions of firm financial performance and labour productivity compared to other firms in their industry. If a positive relationship exists, it would suggest that management in de-collectivised workplaces perceive that they are doing better than similar workplaces, so that there has been some utility in abandoning collective bargaining.

Results, with one exception suggest little relationship between collective bargaining and its absence and managerial perceptions of establishment performance. The exception is reported productivity improvements. Workplaces which have abandoned collective bargaining are less likely to report productivity improvements well above average and more likely to report average or above average improvements. This finding is compatible with the idea that management in workplaces that decollectivised are pursuing a low involvement, cost minimisation approach, resulting in less impressive productivity gains. Because collective bargaining has been abandoned, management have less incentive to improve productivity. However these findings are still slightly surprising because they are at odds with the management accounts of productivity change in Brown et al.'s case studies.

\subsection{Pay dispersion}

It is well established that unions reduce pay dispersion through collective bargaining (Card 2001; Freeman 1980; Metcalf 1982; Metcalf et al. 2001), and that the decline of trade unionism contributed to widening the dispersion of pay in the 1980s (Gosling and Machin 1995; Machin 1997). Prassad (2002) has shown that pay dispersion in Britain continued to widen during the first half of 1990s, albeit at a slower rate than in the 1980s, before stopping in the latter part of the decade. Therefore it seems plausible that decline of collective bargaining also contributed to widening wage dispersion in 
the 1990s. Brown et al.'s case studies provide some corroboration for this hypothesis: "For many firms, the advantage of breaking away from an existing structure of collective bargaining was to increase the dispersion of pay, both within grades and between hierarchical levels.” Brown et al. (1998: i)

Recent research by Addison et al. (2003) and Card et al. (2003) has investigated the link between de-unionisation and widening wage dispersion in Britain. The problem with both of these papers is that they take individual union membership as a proxy for union coverage. Over the course of the period that these papers investigate, open shop unionism became the norm and free-riding amongst workers covered by union bargaining arrangements increased (Charlwood 2003, 2005) so estimates of the estimates of the impact of collective bargaining on the labour market that use union membership as their measure of unionisation will be biased. Specifically, because, by excluding free-riders, they investigate the effects of unions among those workers where union density is likely to be highest and unions strongest, they are likely to overestimate the impact of unions on the labour market. I try to overcome this limitation by performing similar analyses to those of Addison et al. and Card et al. using data from waves 1 (1991) and 7 (1997) of the British Household Panel Survey. These data contain information on both individual wages and union coverage. However, they do suggest a smaller drop in collective bargaining coverage in the 1990s than the WERS data suggest. In the BHPS, union coverage among employees in workplaces with 25 or more employees, from 64 per cent to 57 per cent; a drop of 7 percentage points. The drop in bargaining coverage among fulltime employees (the focus of my analysis) is nearer to, but still less than that found in WERS.

This discrepancy between the WERS and the BHPS may be the result of a number of factors. First, the BHPS missed the decline in coverage that took place in 1990, this may account for around 2 percentage points of the difference. Second, measurement error in the 1990 WERS. If 1990 WERS respondents misclassified workplaces that had recently abandoned collective bargaining as practising collective bargaining, then WERS will overstate the drop in bargaining coverage in the 1990s. Third, measurement error in the BHPS as a result of employees not realising that there employer has abandoned collective bargaining while maintaining union recognition may bias estimates of collective bargaining coverage in 1997 upwards. Finally, even when weighted, the BHPS sample does not fully capture the growth in the number of 
employees and changes in the composition of the workforce between 1991 and 1997, and this may also account for the discrepancy. Overall, it seems likely that WERS has overstated the decline in bargaining coverage slightly as a result of measurement error, while the BHPS has understated it as a result of measurement error and the panel sample. This needs to be borne in mind when interpreting the results.

To estimate the impact of the decline of collective bargaining on wage dispersion it is necessary to start with a counter-factual. Following the approach of Freeman (1993) we could ask what would wage dispersion in 1997 have been given the impact of unions on the labour market in 1997 if collective bargaining coverage was at the level of 1991 ? The following formula operationalises this approach.

$\mathrm{D}_{97}-\mathrm{D}_{97}{ }_{97}=\left(\mathrm{U}_{97}-\mathrm{U}_{91}\right) \Delta_{97 \mathrm{v}}+\left(\mathrm{U}_{97}-\mathrm{U}_{91}\right)\left(1-\mathrm{U}_{97}-\mathrm{U}_{91}\right) \Delta_{97 \mathrm{w}}{ }^{2}$

Where $\mathrm{D}$ equals the impact of unions on the labour market. $\mathrm{U}$ is collective bargaining coverage. $\mathrm{V}$ is variance and $\mathrm{W}$ is wages (so $\Delta \mathrm{V}$ and $\Delta \mathrm{W}$ are the union wage and variance gaps respectively). The problem with this approach is that it does not allow for change in the effects of collective bargaining across the two periods. Decline in collective bargaining coverage may be symptomatic of a decline in union power, and any increase in collective bargaining coverage may also alter the impact of collective bargaining. Card (2001) proposes an alternative framework that takes into account the changing impact of unions:

$\mathrm{D}_{97}-\mathrm{D}_{91}=\mathrm{V}_{97}-\mathrm{V}_{91}-\left(\mathrm{V}_{97}^{\mathrm{n}}-\mathrm{V}_{91}^{\mathrm{n}}\right)=\mathrm{U}_{97} \Delta_{97} \mathrm{~V}-\mathrm{U}_{91} \Delta_{91} \mathrm{~V}+\mathrm{U}_{97}\left(1-\mathrm{U}_{97}\right) \Delta_{97} \mathrm{~W}^{2}-\mathrm{U}_{91}\left(1-\mathrm{U}_{91}\right) \Delta_{91} \mathrm{~W}^{2}$

Where $\mathrm{V}^{\mathrm{n}}$ is the variance in the non-union sector. Note that both formulas calculate 'naïve' estimates of the impact of de-unionisation on wage dispersion because they assume that the impact of unions is homogenous across skill groups. In reality, the impact of collective bargaining varies according to the skill of the worker and the impact of collective bargaining on skill groups changes over time. Card (2001) proposes a methodology for estimating the impact of de-unionisation on wage dispersion that accounts for the differential impact of collective bargaining on skill groups. However, I lack the space in this short paper to follow Card's (2001) methodology in full. 
Table seven reports key descriptive statistics for 1991 and 1997 for full-time men and full-time women earning between $£ 1$ and $£ 45$ per hour in 1997 pounds; the percentage covered by collective bargaining, the variance in the union and non-union sectors and mean log hourly wage. This shows that variance increased most among unionised men and non-union women, and that the variance actually decreased for unionised women. Table eight reports the impact of collective bargaining on wage dispersion in 1991 and 1997 and calculates the results of equations three and four.

Overall, table eight shows that variance increased from 0.269 to 0.298 for full-time men, while falling slightly from 0.251 to 0.249 for full-time women. Taking full-time men first, table eight reveals that if collective bargaining coverage had remained at the level of 1991, while the union impact on the labour market had remained the same, the increase in the variance observed between 1991 and 1997 would have been a third less than it actually was. However, the key change in the union impact on the labour market between 1991 and 1997 was the increase in wage dispersion within the union sector. This change accounts for all of the increase in overall wage dispersion.

For women, given the slight overall reduction in wage dispersion in the union sector between 1991 and 1997, it is unsurprising to find that wage dispersion would have been lower if collective bargaining coverage had remained at the 1991 level. Even though collective bargaining coverage fell between 1991 and 1997, collective bargaining stopped wage dispersion among women from increasing because of the increasingly egalitarian impact of unions on women's pay in the union sector.

The key caveat to bear in mind when considering these results is that they are based on 'naïve' estimates that do not take account of the differential impact of unions on skill groups. In the calculations of Card et al (2003) and Addison et al. (2003) the impact of unions on wage dispersions was reduced once the differential impact of unions on skill groups was taken into account. Nevertheless, these results, based on bargaining coverage suggest that the for men at least, the decline of collective bargaining and union power did contribute to widening wage dispersion to a much 
greater extent than estimates calculated using union membership as a proxy for coverage (Card et al 2003, Addison et al. 2003) suggest.

\section{Summary and conclusions}

The de-collectivisation of pay setting was a highly significant feature of British employment relations in the 1990s. In marked contrast to the 1980s management in unionised workplaces took advantage of trade union weakness move away from pay determination through collective bargaining. Almost one in three continuing workplaces that practised collective bargaining in 1990 had stopped bargaining over pay by 1998, yet union de-recognition remained rare. This suggests that management in these workplaces either substantially re-negotiated the content of collective agreements, or simply ceased to bargain without bothering to formally de-recognise the union. New workplaces were also significantly less likely to recognise trade unions than the workplaces that they replaced. Workplaces were more likely to abandon collective bargaining if they had lower levels of union density in 1990, were in the water, gas and electricity supply sector or had a high proportion of female employees. Overall, The abandonment of bargaining in continuing workplaces accounted for around one quarter of the overall decline. The remaining three quarters was due to the lower incidence of bargaining in new workplaces compared to the workplaces that they replaced.

These changes do not seem to have bought about substantive individualisation of pay setting, although there are signs that this may be on the increase because new workplaces without collective bargaining are more likely to use non-standard employment contracts.

At first glance, de-collectivisation of pay setting in continuing workplaces does not seem to have contributed to economic efficiency. Private sector workplaces that de-collectivised were less likely to follow a high involvement management approach. Contrary to the findings of Brown et al. (1998) management were less likely to report productivity growth that was well above average for their industry.

De-collectivisation also had a significant impact on widening wage inequality among men (but not among full-time women). Among men, income inequality grew as a result of widening wage dispersion among those who remained covered by 
collective bargaining. It seems likely that widening wage inequality in the union sector and the decline of collective bargaining were both symptoms of deeper union weaknesses. However, more research needs to be done to establish the credibility of the BHPS as a data-source for investigating wage dispersion, to understand the differences between estimates based on membership compared to estimates based on coverage and to take into account the differential impact of collective bargaining on different skill groups.

Against these (to my mind) negative outcomes of de-collectivisation must be set the finding that workplaces that de-collectivised pay setting were significantly more likely to have experienced employment growth. Given the negative effects of unemployment on well-being (Layard 2004), a 'bad job' may be better than no job.

Overall these findings raise questions about the Britain's labour market performance in the 1990s because they suggest that Britain's comparatively low levels of unemployment were achieved through a 'low road' low productivity route and widening inequality as a result of declining union power. Therefore the important policy question of how to combine high productivity growth with high levels of employment, employment growth and social justice remains open.

\section{End notes}

1. One possible explanation for this finding might be workplaces in the public sector switching out of collective bargaining in favour of pay review bodies (PRBs). In theory, any workplace with a pay review body in place in 1998 should have had a PRB in place in 1990 (e.g. nursing) or have already abandoned collective bargaining even if a PRB was not established until after 1990 (e.g. school teachers). However, we cannot totally discount the possibility that some of these workplaces may have misreported their collective bargaining status and coverage in 1990.

2. Millward et al. (1998: 103) found that just 6 per cent of continuing workplaces derecognised unions, my results suggest that only one third of de-recognition cases resulted in total union de-recognition.

3. To economise on space, these results are not presented here, but are available from the author on request.

4. It would also be interesting to test whether changes in product market competition are associated with de-collectivisation (Beaumont \& Harris, 1995). Data collection errors in the 1990 WERS make this impossible. Beaumont and Harris also show that declining union density predicted de-recognition. This approach is not pursued here because it raises a chicken and egg question; which came first, falling density or derecognition? 
5. Results were identical to the results of a bivariate probit analysis of the whole sample which first conditioned for whether or not a workplace had collective bargaining in 1990. The results of the univariate probit on workplaces with collective bargaining are presented for simplicity.

6. In preliminary analyses I also experimented with the measure of high involvement management developed by Forth and Millward (2004). The problem with Forth and Millward's approach was that two of their measures of a high involvement approach (extensive use of financial participation schemes and employment security guarantees) were heavily correlated with union recognition. Consequently it is not really an appropriate way to operationalize Purcell and Ahlstrand's typology, which sees HIM as an alternative to traditional collective bargaining. 


\section{References}

Addison, John T., Ralph Bailey and W. Stanley Seibert (2003) 'The Impact of Deunionisation on Earnings Dispersion Revisited', IZA Discussion Paper 724, Bonn.

Addison, John T. and Belfield, Clive R. (2001) 'Updating the Determinants of Firm Performance: Estimation Using the 1998 WERS' British Journal of Industrial Relations, 39(2): 341 - 366.

Addison, John T. and Belfield, Clive R. (2004) 'Unions and Employment Growth: The One Constant?' Industrial Relations, 43(2):

Beaumont, Philip and Richard I.D. Harris (1995) 'Union De-Recognition and Declining Union Density in Britain' Industrial and Labor Relations Review 48(3): $389-402$.

Brown, William and Sushil Wadhwani (1990) 'The Economic Effects of Industrial Relations Legislation Since 1979’ National Institute Economic Review, 131 (February): 57 - 70.

Brown, William, Simon Deakin and Paul Ryan (1997) 'The Effects of British Industrial Relations Legislation 1979 - 97' National Institute Economic Review, 161 (April), pp. $69-83$.

Brown, William, Simon Deakin, Maria Hudson, Cliff Pratten and Paul Ryan, (1998) The Individualisation of the Employment Contract in Britain. Department of Trade and Industry, Employment Relations Research Series 5. London: DTI, available at www.dti.gov.uk/emar

Brown, William, Paul Marginson and Janet Walsh (2002) 'Pay Determination' in Paul Edwards (ed.) Industrial Relations: Theory and Practice, Blackwell: Oxford.

Bryson, Alex (2002) The Union Membership Wage Premium: An Analysis using Propensity Score Matching, Centre for Economic Performance Discussion Paper 530, London: CEP.

Card, David (2001) 'The Effect of Unions on Wage Inequality in the US Labor Market' Industrial and Labor Relations Review 54(2): 296 - 315.

Card, David, Thomas Lemieux and W. Craig Riddell (2003) 'Unionization and Wage Inequality: A Comparative Study of the US, the UK and Canada' Working Paper 9473, National Bureau for Economic Research, Cambridge MA.

Claydon, Tim (1989) 'Union De-recognition in Britain in the 1980s' British Journal of Industrial Relations, 27(2): $214-25$.

Charlwood, Andy (2003) The Anatomy of Union Decline in Britain 1990 - 1998. Centre for Economic Performance Working Paper 1224, London: CEP. 
Charlwood, Andy (2005) The Anatomy of Trade Union Membership Decline in Great Britain 1980 - 1998, unpublished PhD thesis, University of London.

Dunn, Stephen and David Metcalf (1996) 'Trade Union Law Since 1979' in Ian Beardwell (ed) Contemporary Industrial Relations: A Critical Analysis, Oxford: Oxford University Press: 66-98.

Freeman, Richard (1980) 'Unionism and the Dispersion of Wages' Industrial and Labor Relations Review, 34(1): 3 - 23.

Freeman, Richard (1993) 'How Much Has De-unionization Contributed to the rise in Male Earnings Inequality?' in S. Danziger and P. Gottschalk (eds.) Uneven Tides: Rising Inequality in America. New York: Russell Sage Foundation.

Forth, John (2000) Compositional versus Behavioural Change: Combined Analysis of the WERS98 Panel Survey, Closures and New Workplaces paper presented to the $1^{\text {st }}$ WERS98 User Group Meeting, http://www.niesr.ac.uk/niesr/wers98

Forth, John, and Neil Millward, (2004) 'High Involvement Management and Pay in Britain' Industrial Relations, 43(1): 98 - 119.

Gosling, Amanda and Stephen Machin (1995) 'Trade Unions and the Dispersion of Earnings in British Establishments, 1980 - 1990' Oxford Bulletin of Economics and Statistics, 57(2): $167-184$.

Gosling, Amanda (1998) The Determination of Union Status and Wages in British Establishments, University of Essex Department of Economics discussion paper 491.

Kersley, B. Alpin, C., Forth, J. Bryson, A. Bewley, H. Dix, G. and Oxenbridge, S. (2005) Inside The Workplace: first findings of the 2004 Workplace Employee Relations Survey, London: Department of Trade and Industry.

Kelly, John (1990) 'British Trade Unionism 1979 - 89: Change, Continuity and Contradictions, Work, Employment and Society, May: 29 - 65.

Layard, R. (2004) Good jobs and bad jobs, Centre for Economic Performance Occasional Paper 19, London: London School of Economics.

Machin, Stephen (1997) 'The Decline of Labour Market Institutions and the rise of wage inequality in Britain' European Economic Review, 41: 647 - 657.

McCarthy, William E.J. (1994) "Of Hats and Cattle: or the Limits of Macro-Survey Research in Industrial Relations", Industrial Relations Journal, 25(4): 315-322.

Metcalf, David (1982) 'Unions and the Distribution of Earnings' British Journal of Industrial Relations, 20(2): 163 - 169.

Metcalf, D. (1989) 'Water Notes Dry Up: The Impact of the Donovan Reform Proposals and Thatcherism on Labour Productivity in British Manufacturing', British Journal of Industrial Relations 27(1): 1-31. 
Metcalf, David (2001) 'British Unions: Dissolution or Resurgence Revisited' in

Dickens, R., Wadsworth, J. and Gregg, P. The State of Working Britain Update 2001. London: Centre for Economic Performance.

Metcalf, David, Kirstine Hansen and Andy Charlwood (2001) 'Trade Unions and the Sword of Justice' National Institute Economic Review.

Millward, Neil, Alex Bryson, and John Forth, (2000) All Change at Work: British employment relations 1980 - 1998 as portrayed by the Workplace Industrial Relations Survey series, London: Routledge.

Millward, Neil and John Forth (2000) The Determinants of Pay Levels and Fringe Benefit Provision in Britain, National Institute for Economic and Social Research Discussion Paper 171, London: NIESR.

Milner, Simon. (1995) 'The Coverage of Collective Pay-setting Institutions in Britain, 1895 - 1990’ British Journal of Industrial Relations 33(1): 70 - 90.

Nolan, Peter and Paul Marginson (1990) 'Skating on Thin Ice? David Metcalf on Trade Unions and Productivity’ British Journal of Industrial Relations, 28(2): 227 266.

Pencavel, John (2003) 'The Surprising Retreat of Union Britain', NBER working paper, forthcoming in Richard Blundell, David Card, and Richard B. Freeman (eds.) Seeking a Premier League Economy, Chicago: University of Chicago Press.

Prasad, Ewar. (2002) Wage Inequality in the United Kingdon, 1975 - 99. IZA Discussion Paper 510, Bonn: IZA.

Purcell, John and Bruce Ahlstrand (1994) Human Resource Management in the Multi Divisional Company. Oxford: OUP.

Purdon, Susan. and Pickering, K. (2001) The Use of Sampling Weights in the Analysis of the 1998 Workplace Employee Relations Survey, London: National Centre for Social Research.

Smith, Paul and Gary Morton (1993) 'Union Exclusion and the De-collectivisation of industrial Relations in Contemporary Britain', British Journal of Industrial Relations 31(1): 97 - 114.

Stewart, Mark. (1983) 'On Least Squares Estimates when the Dependent Variable is Grouped' Review of Economic Studies 50(4): 737 - 753.

Taylor, Marcia Freed (ed). With John Brice, Nick Buck and Elaine Prentice-Lane (2001) British Household Panel Survey User Manual Vol. A, Colchester: University of Essex.

Wood, Stephen (1999) 'HRM and Performance' International Journal of Management Reviews, 1(4): 387 - 413. 
Wood, Stephen, Lillian De Menezes and Ana Lasaosa (2000) 'The Nature and Determinants of High Involvement Management in the UK: An Analysis using WERS98' Mimeo, Institute of Work Psychology, Sheffield: IWP. 
Table 1 - The incidence and coverage of collective bargaining among British workplaces ${ }^{1} 1990-1998$

\begin{tabular}{|c|c|c|c|c|c|c|c|c|c|c|}
\hline & \multicolumn{2}{|c|}{$\begin{array}{c}\text { Incidence of } \\
\text { collective } \\
\text { bargaining } \\
\text { (\% of } \\
\text { workplaces } \\
\text { with } \\
\text { coverage } \\
>0)\end{array}$} & \multicolumn{2}{|c|}{$\begin{array}{c}\text { Mean } \\
\text { bargaining } \\
\text { coverage in } \\
\text { workplaces } \\
\text { where } \\
\text { bargaining } \\
\text { coverage is } \\
>0\end{array}$} & \multicolumn{2}{|c|}{$\begin{array}{l}\text { Incidence of } \\
\text { collective } \\
\text { bargaining } \\
\text { coverage in } \\
\text { continuing } \\
\text { (panel) } \\
\text { workplaces }\end{array}$} & \multicolumn{2}{|c|}{$\begin{array}{c}\text { Incidence of } \\
\text { collective } \\
\text { bargaining } \\
\text { in leavers } \\
(1990) \text { and } \\
\text { joiners } \\
(1998)\end{array}$} & \multicolumn{2}{|c|}{$\begin{array}{c}\text { Aggregate } \\
\text { collective } \\
\text { bargaining } \\
\text { coverage }\end{array}$} \\
\hline & 1990 & 1998 & 1990 & 1998 & 1990 & 1998 & 1990 & 1998 & 1990 & 1998 \\
\hline $\begin{array}{l}\text { Public } \\
\text { Sector }\end{array}$ & 85.6 & 78.6 & 75.6 & 84.3 & 97 & 77.1 & 90 & 69.8 & 74.8 & 62.9 \\
\hline $\begin{array}{l}\text { Private } \\
\text { Sector }\end{array}$ & 57.7 & 30.8 & 72.7 & 76.5 & 59.5 & 48.3 & 56.8 & 26.8 & 40.6 & 26.6 \\
\hline All & 67.4 & 44.5 & 74.3 & 80.8 & 71.2 & 53.7 & 62.8 & 38.7 & 53.6 & 38.1 \\
\hline
\end{tabular}

Source: WIRS 90, WERS98 and WERS98 panel. Weighted base: 2061 (1990 crosssection), 1929 (1998 cross-section), 379 (1990 leavers), 390 (1998 joiners), 823 (1990 panel), 846 (1998 panel)

1) Workplaces with 25 or more employees 
Table 2 - The components of decline in aggregate collective bargaining coverage $1990-1998$

\begin{tabular}{|l|l|l|l|}
\hline & $\begin{array}{l}\text { Leavers and } \\
\text { joiners }\end{array}$ & $\begin{array}{l}\text { Continuing } \\
\text { workplaces }\end{array}$ & $\begin{array}{l}\text { All } \\
\text { workplaces }\end{array}$ \\
\hline $\begin{array}{l}\text { Public Sector } \\
\text { Compositional } \\
\text { change }\end{array}$ & -0.47 & -5.36 & -5.83 \\
$\begin{array}{l}\text { Behavioural change } \\
\text { Interaction term }\end{array}$ & 1.12 & -13.26 & -12.14 \\
$\begin{array}{l}\text { Total } \\
\text { Private Sector }\end{array}$ & 1.56 & 1.46 & 3.02 \\
$\begin{array}{l}\text { Compositional } \\
\text { change }\end{array}$ & $\mathbf{2 . 2 1}$ & $\mathbf{- 1 7 . 1 6}$ & $\mathbf{- 1 4 . 9 5}$ \\
$\begin{array}{l}\text { Behavioural change } \\
\text { Interaction term }\end{array}$ & -1.15 & 1.22 & 0.075 \\
$\begin{array}{l}\text { Total } \\
\text { All Workplaces } \\
\text { Compositional } \\
\text { change }\end{array}$ & 0.19 & -3.63 & -14.56 \\
$\begin{array}{l}\text { Behavioural change } \\
\text { Interaction term }\end{array}$ & -0.057 & 0.21 & 0.4 \\
Total & -3.46 & $\mathbf{- 2 . 1 9}$ & $\mathbf{- 1 4 . 0 8}$ \\
& -0.052 & -4.05 & -4.62 \\
\hline
\end{tabular}

Notes: Calculated from the results reported in table A1 using multivariate shift-share analysis. 
Table 3 - the determinants of de-collectivisation of pay setting 1990 - 98 in workplaces with collective bargaining in 1990

\begin{tabular}{|c|c|c|}
\hline & Mean & $\begin{array}{l}\text { Marginal } \\
\text { effect } \\
\text { (standard } \\
\text { error) }\end{array}$ \\
\hline Trade union density in 1990 & 71.08 & $\begin{array}{l}-0.005 * * * \\
(0.0016)\end{array}$ \\
\hline $\begin{array}{l}\text { Level of collective bargaining in } 1990 \text { (ref. organisation } \\
\text { wide bargaining) }\end{array}$ & & \\
\hline Industry collective bargaining & 0.447 & $\begin{array}{l}0.126 \\
(0.09)\end{array}$ \\
\hline 'Double-breasting' arrangements & 0.028 & $\begin{array}{l}0.1755 \\
(0.18)\end{array}$ \\
\hline Workplace collective bargaining & 0.169 & $\begin{array}{l}0.374 * * \\
(0.14)\end{array}$ \\
\hline Change in ownership $1990-98$ & 0.155 & $\begin{array}{l}0.009 \\
(0.008)\end{array}$ \\
\hline Public sector in 1990 & 0.613 & $\begin{array}{l}0.003 \\
(0.11)\end{array}$ \\
\hline Privatised 1990 - 1998 & 0.031 & $\begin{array}{l}-0.011 \\
(0.24)\end{array}$ \\
\hline Proportion of full-time women in 1990 & 31.7 & $\begin{array}{l}0.005^{* *} \\
(0.0026)\end{array}$ \\
\hline Industry in 1990 (ref. manufacturing) & & \\
\hline Gas, electricity and water & 0.012 & $\begin{array}{l}0.563 * * \\
(0.253)\end{array}$ \\
\hline $\begin{array}{l}\text { Workplace size in } 1990 \text { (ref. } 250 \text { - } 499 \text { employees) } \\
25 \text { - } 99 \text { employees }\end{array}$ & 0.708 & $\begin{array}{l}-0.036 \\
(0.094)\end{array}$ \\
\hline $100-249$ employees & 0.182 & $\begin{array}{l}0.122 \\
(0.109)\end{array}$ \\
\hline $500+$ employees & 0.032 & $\begin{array}{l}-0.108 \\
(0.058)\end{array}$ \\
\hline Change to a lower size band $1990-1998$ & 0.086 & $\begin{array}{l}-0.069 \\
(0.079)\end{array}$ \\
\hline Change to a higher size band $1990-98$ & 0.09 & $\begin{array}{l}0.27 * * \\
(0.108)\end{array}$ \\
\hline Mean predicted probability of de-collectivised pay-setting & & 0.17 \\
\hline $\mathrm{F}(33,349)$ & & 1.97 \\
\hline Prob $>$ F & & 0.0015 \\
\hline Weighted N & 382 & 382 \\
\hline
\end{tabular}

Calculated from the results of a weighted probit regression. $*=$ statistically significant at the $5 \%$ level or better, $* *=$ statistically significant at the $1 \%$ level or better. Controls: Industry (1 digit SIC), change in industry 1990 - 98, occupational composition of the workforce, proportion of the workforce part-timers, change in workforce composition 1990 - 98. 
For continuous variables (e.g. union density) the marginal effect can be interpreted as the change in predicted probability of de-collectivising if there is a one per cent increase in union density. For dummy variables (e.g. the level of collective bargaining in 1990) the marginal effect is the change in the predicted probability if the dummy variable changes from zero to one. 
Table 4 - Marginal effects from probit analyses of the determinants of individualised of pay-setting arrangements

\begin{tabular}{|c|c|c|c|}
\hline & $\begin{array}{c}\text { USE OF NON- } \\
\text { STANDARD } \\
\text { CONTRACTS }\end{array}$ & $\begin{array}{c}\text { INDIVIDUAL } \\
\text { NEGOTIATIONS } \\
\text { INCREASING IN } \\
\text { IMPORTANCE }\end{array}$ & $\begin{array}{l}\text { PERFORMANCE } \\
\text { RELATED PAY }\end{array}$ \\
\hline $\begin{array}{l}\text { Omitted reference } \\
\text { category: } \\
\text { Continuing } \\
\text { workplace with } \\
\text { collective } \\
\text { bargaining }\end{array}$ & & & \\
\hline $\begin{array}{l}\text { New workplace } \\
\text { with collective } \\
\text { bargaining }\end{array}$ & $\begin{array}{l}-0.084 \\
(0.5)\end{array}$ & & $\begin{array}{l}-0.15 \\
(0.072)\end{array}$ \\
\hline $\begin{array}{l}\text { De-collectivised } \\
\text { workplace }\end{array}$ & $\begin{array}{l}-0.008 \\
(0.05)\end{array}$ & $\begin{array}{l}-0.14 \\
(0.043)\end{array}$ & $\begin{array}{l}-0.089 \\
(0.041)^{* *}\end{array}$ \\
\hline $\begin{array}{l}\text { Continuing } \\
\text { workplace with no } \\
\text { collective } \\
\text { bargaining }\end{array}$ & $\begin{array}{l}0.047 \\
(0.047)\end{array}$ & $\begin{array}{l}-0.039 \\
(0.039)\end{array}$ & $\begin{array}{l}0.062 \\
(0.048)\end{array}$ \\
\hline $\begin{array}{l}\text { New workplace } \\
\text { with no collective } \\
\text { bargaining }\end{array}$ & $\begin{array}{l}0.078 \\
(0.063)\end{array}$ & - & $\begin{array}{l}0.042 \\
(0.062)\end{array}$ \\
\hline $\begin{array}{l}\text { Predicted } \\
\text { probability at the } \\
\text { sample mean }\end{array}$ & 0.19 & 0.14 & 0.254 \\
\hline $\begin{array}{l}\text { Probability }>\text { chi }^{2} \\
\text { N }\end{array}$ & $\begin{array}{l}0.000 \\
1503\end{array}$ & $\begin{array}{l}0.001 \\
1124\end{array}$ & $\begin{array}{l}0.000 \\
1506\end{array}$ \\
\hline
\end{tabular}

Notes

1. Controls: Workplace size (banded), private sector, occupational composition of the workforce, industry, establishment age.

2. Regressions were run on data weighted with probability weights.

3. Standard errors are in parentheses.

4. $*=$ statistically significant at the $5 \%$ level, $* *=$ statistically significant at the $1 \%$ level, 5. The question about individual negotiation was only asked in continuing workplaces. 
Table 5 - Marginal effects from an ordered probit analysis on the determinants of high involvement management

\begin{tabular}{|c|c|c|c|c|c|c|c|c|c|}
\hline & All & & & Public & & & Private & & \\
\hline $\begin{array}{l}\text { Omitted } \\
\text { ref: } \\
\text { Continuing } \\
\text { workplace } \\
\text { with } \\
\text { collective } \\
\text { bargaining }\end{array}$ & HIM & $\begin{array}{l}\text { Medium } \\
\mathrm{m}\end{array}$ & Low & HIM & $\begin{array}{l}\text { Mediu } \\
\mathrm{m}\end{array}$ & Low & HIM & $\begin{array}{l}\text { Mediu } \\
\mathrm{m}\end{array}$ & Low \\
\hline $\begin{array}{l}\text { New } \\
\text { workplace } \\
\text { with } \\
\text { collective } \\
\text { bargaining }\end{array}$ & $\begin{array}{l}-0.01 \\
(0.07 \\
)\end{array}$ & $\begin{array}{l}0.003 \\
(0.016)\end{array}$ & $\begin{array}{l}0.008 \\
(0.05)\end{array}$ & $\begin{array}{l}-0.024 \\
(0.06)\end{array}$ & $\begin{array}{l}0.013 \\
(0.03)\end{array}$ & $\begin{array}{l}0.012 \\
(0.03)\end{array}$ & 0.001 & $<0.000$ & $<0.000$ \\
\hline $\begin{array}{l}\text { De- } \\
\text { collectivised }\end{array}$ & $\begin{array}{l}- \\
0.047 \\
(0.05)\end{array}$ & $\begin{array}{l}0.01 \\
(0.007)\end{array}$ & $\begin{array}{l}0.037 \\
(0.039 \\
)\end{array}$ & $\begin{array}{l}0.053 \\
(0.07)\end{array}$ & $\begin{array}{l}-0.03 \\
(0.04)\end{array}$ & $\begin{array}{l}-0.023 \\
(0.03\end{array}$ & $\begin{array}{l}-0.11 \\
(0.05)^{*} \\
*\end{array}$ & $\begin{array}{l}-0.001 \\
(0.017)\end{array}$ & $\begin{array}{l}0.111 \\
(0.06) \\
*\end{array}$ \\
\hline $\begin{array}{l}\text { Continuing } \\
\text { workplace } \\
\text { with no } \\
\text { collective } \\
\text { bargaining }\end{array}$ & $\begin{array}{l}0.002 \\
(0.05 \\
)\end{array}$ & $\begin{array}{l}0.001 \\
(0.012)\end{array}$ & $\begin{array}{l}0.001 \\
(0.03)\end{array}$ & $\begin{array}{l}0.064 \\
(0.187 \\
)\end{array}$ & $\begin{array}{l}-0.038 \\
(0.12)\end{array}$ & $\begin{array}{l}-0.026 \\
(0.064 \\
)\end{array}$ & $\begin{array}{l}0.037 \\
(0.05)\end{array}$ & $\begin{array}{l}-0.007 \\
(0.01)\end{array}$ & $\begin{array}{l}0.03 \\
(0.04)\end{array}$ \\
\hline $\begin{array}{l}\text { New } \\
\text { workplace } \\
\text { with no } \\
\text { collective } \\
\text { bargaining }\end{array}$ & $\begin{array}{l}0.002 \\
(0.05 \\
)\end{array}$ & $\begin{array}{l}-0.001 \\
(0.015)\end{array}$ & $\begin{array}{l}-0.001 \\
(0.07)\end{array}$ & $\begin{array}{l}0.265 \\
(0.12) \\
*\end{array}$ & $\begin{array}{l}-0.193 \\
(0.105)\end{array}$ & $\begin{array}{l}-0.072 \\
(0.024 \\
)\end{array}$ & $\begin{array}{l}-0.056 \\
(0.058)\end{array}$ & $\begin{array}{l}0.008 \\
(0.008)\end{array}$ & $\begin{array}{l}0.038 \\
(0.05)\end{array}$ \\
\hline $\begin{array}{l}\text { Mean } \\
\text { probability } \\
\text { of being in } \\
\text { category } \\
\text { F } \\
\text { Probability } \\
>\text { chi }^{2} \\
\text { N }\end{array}$ & $\begin{array}{l} \\
3.01 \\
0.000 \\
1430\end{array}$ & 0.55 & 0.16 & $\begin{array}{l}0.3 \\
\\
2.20 \\
0.001 \\
401\end{array}$ & 0.61 & 0.09 & $\begin{array}{l} \\
2.82 \\
0.000 \\
1029\end{array}$ & 0.54 & 0.18 \\
\hline
\end{tabular}

Notes

1. Controls: Workplace size (banded), private sector, occupational composition of the workforce, industry, establishment age.

2. Regressions were run on data weighted with probability weights.

3. Standard errors are in parentheses.

4. $*=$ statistically significant at the $5 \%$ level, $* *=$ statistically significant at the $1 \%$ level, 5 . The question about individual negotiation was only asked in continuing workplaces. 
Table 6 - Marginal effects from ordered probit analyses on the determinants of managerial perceptions of establishment performance

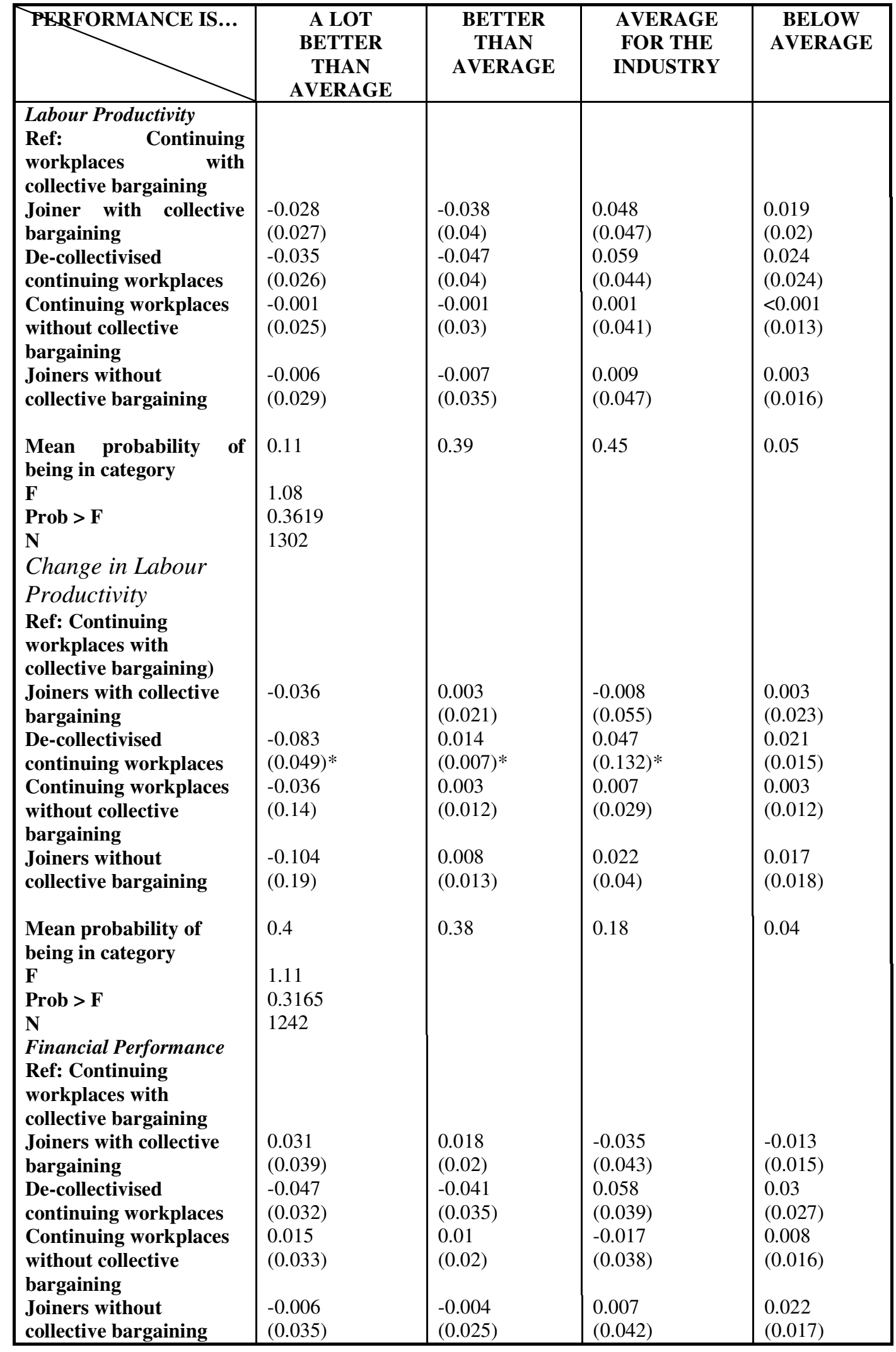




\begin{tabular}{|l|l|l|l|l|}
\hline $\begin{array}{l}\text { Mean probability of } \\
\text { being in category }\end{array}$ & 0.15 & 0.43 & 0.36 & 0.06 \\
$\mathbf{F}$ & 2.64 & & & \\
Prob $>$ F & 0.0000 & & & \\
$\mathbf{N}$ & 1301 & & & \\
\hline
\end{tabular}

Marginal effects calculated from the results of ordered probit regressions. Results can be interpreted as the change (from the mean) in the predicted probability of a workplace falling into a particular performance category.

$*$ = Statistically significant at the 1 per cent level, $* *=$ statistically significant at the five per cent level. $\mathrm{N}=1242$ (labour productivity), 1301 (productivity change), 1302 (financial performance).

Controls: Workplace size (banded), Workforce composition, 1 digit industry classification,

establishment age, single establishment organisation, foreign owned organisation, private sector.

Table 7 - Union coverage, hourly wages and wage dispersion for employees by collective bargaining coverage in 1991 and 1997

\begin{tabular}{|l|ll|lc|}
\hline & Full-time men & \multicolumn{2}{l|}{ Full-time women } \\
\hline 1991 & Union & Non-union & Union & Non-union \\
& & & & \\
\% of employees & $\mathbf{5 7 . 1}$ & $\mathbf{4 2 . 9}$ & 55.2 & 44.8 \\
Variance & $\mathbf{0 . 2 0 8}$ & $\mathbf{0 . 3 3 7}$ & 0.203 & 0.253 \\
Mean log hourly wage & $\mathbf{1 . 9 8}$ & $\mathbf{1 . 8 0}$ & 1.77 & 1.98 \\
& & & & \\
\hline 1997 & & & & 55.2 \\
& & & & 0.278 \\
\% of employees & 45.7 & 54.3 & 44.8 & 1.88 \\
Variance & 0.249 & 0.344 & 0.19 & \\
Mean log wage & 2.0 & 1.88 & 1.84 & \\
& & & &
\end{tabular}

Samples from waves 1 and 7 of the British Household Panel Survey. Respondents are full-time employees in employment whose hourly wage were between $£ 1$ and $£ 45$ in 1991 points (1997 wages deflated by the retail price index). All results were weighted by cross-sectional weights. 
Table 8 - Naïve estimates of the contribution of Unions to rising wage inequality between 1991 and 1997

\begin{tabular}{|l|l|l|}
\hline & Men & Women \\
\hline 1991 & & \\
\hline 1.1. Variance in log wages & 0.269 & 0.251 \\
\hline 1.2. Collective bargaining coverage & 57.1 & 55.2 \\
\hline 1.3. Adjusted union wage gap & 0.075 & 0.147 \\
\hline 1.4. Union variance gap & -0.129 & -0.050 \\
\hline 1.5. Between sector effect & 0.001 & 0.036 \\
\hline 1.6. Within sector effect & -0.074 & -0.028 \\
\hline 1.7. total effect & -0.072 & 0.009 \\
\hline 1997 & & \\
\hline 2.1. Variance in log wages & 0.298 & 0.249 \\
\hline 2.2. Collective bargaining coverage & 45.7 & 44.8 \\
\hline 2.3. Adjusted union wage gap & 0.064 & 0.093 \\
\hline 2.4. Union variance gap & -0.095 & 0.008 \\
\hline 2.5. Between sector effect & 0.001 & 0.002 \\
\hline 2.6. Within sector effect & -0.043 & -0.039 \\
\hline 2.7. total effect & -0.042 & -0.037 \\
\hline Changes in wage dispersion 1991 - 1997 & & \\
\hline 3.1. Change in variance & 0.029 & -0.008 \\
\hline $\begin{array}{l}\text { 3.2. Change in variance (\%) directly attributable to the decline in } \\
\text { bargaining coverage (Freeman 1993) }\end{array}$ & 36 & 113 \\
\hline $\begin{array}{l}\text { 3.3. Change in total effects of collective bargaining on the wage } \\
\text { structure }\end{array}$ & 0.03 & -0.046 \\
\hline $\begin{array}{l}\text { 3.4. Change in variance (\%) attributable to change in effects of } \\
\text { collective bargaining (including change in coverage) (Card 2001) }\end{array}$ & 103 & -187 \\
\hline Note: All & & \\
\hline
\end{tabular}

Note: All results were weighted by cross-sectional weights. The adjusted union wage gap is the union coefficient from a regression analysis controlling for education, potential labour market experience in years, potential experience squared and cubed, education interacted with experience and dummies for non-white ethnic status, marital status, 4 regions, the public sector and workplaces that employ 25 or fewer people. 


\section{CENTRE FOR ECONOMIC PERFORMANCE \\ Recent Discussion Papers}

704 Michael W. L. Elsby

703 David Marsden Richard Belfield

702 John Van Reenen

701 Joas Santos Silva Silvana Tenreyro

700 Alan Manning Joanna Swaffield

699 Andrew B. Bernard Stephen Redding Peter K. Schott

698 Nicholas Oulton

697 Alan Manning

696 Andrew B. Bernard Stephen Redding Peter K. Schott

695 Henry G. Overman Anthony J. Venables

694 Carlo Rosa Giovanni Verga

693 Richard Dickens Mirko Draca

692 Ralf Martin
Evaluating the Economic Significance of Downward Nominal Wage Rigidity

Performance Pay for Teachers Linking Individual and Organisational Level Targets

The Growth of Network Computing: Quality Adjusted Price Changes for Network Servers

The Log of Gravity

The Gender Gap in Early Career Wage Growth

Products and Productivity

Ex Post Versus Ex Ante Measures of the User Cost of Capital

You Can't Always Get What You Want: the Impact of the Jobseeker's Allowance

Factor Price Equality and the Economies of the United States

Cities in the Developing World

The Importance of the Wording of the ECB

The Employment Effects of the October 2003

Increase in the National Minimum Wage

Computing the True Spread 
691 Augustin de Coulon

François-Charles Wolff

690

Monika Merz

Eran Yashiv

689 Pierre-Philippe Combes

Giles Duranton

Henry G. Overman

688 Stephen Redding

Daniel M. Sturm

687 Vicente Cuñat

Maria Guadalupe

686 Maria Guadalupe

685 Jo Blanden

Stephen Machin

John Van Reenen

684 Giovanna Vallanti

683 Gilles Duranton

Michael Storper

682 Carlo Rosa

Giovanni Verga

681 Nicholas Oulton

Sylaja Srinivasan

680 Stephen Machin

Olivier Marie

679 Alan Manning

Barbara Petrongolo
Immigrants at Retirement: Stay/Return or 'Va-etVient'?

Labor and the Market Value of the Firm

Agglomeration and the Adjustment of the Spatial Economy

The Costs of Remoteness: Evidence from German Division and Reunification

How Does Product Market Competition Shape Incentive Contracts?

Product Market Competition, Returns to Skill and Wage Inequality

New Survey Evidence on Recent Changes in UK Union Recognition

Capital Mobility and Unemployment Dynamics:

Evidence from a Panel of OECD Countries

Rising Trade Costs? Agglomeration and Trade with Endogenous Transaction Costs

Is ECB Communication Effective?

Productivity Growth and the Role of ICT in the United Kingdom: An Industry View, 1970-2000

Crime and Police Resources: the Street Crime Initiative

The Part-Time Pay Penalty

\section{The Centre for Economic Performance Publications Unit Tel 02079557673 Fax 02079557595 Email info@cep.lse.ac.uk Web site http://cep.lse.ac.uk}

